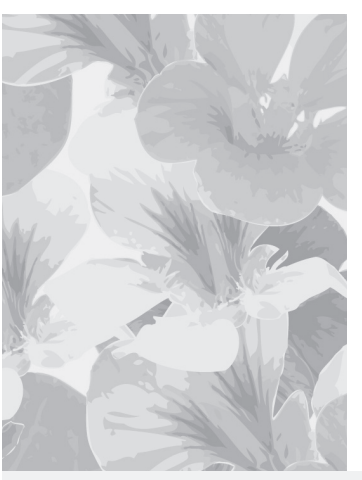

\title{
Wszystkie chwyty dozwolone?
}

\author{
All tricks allowed? \\ Andrzej Ignaciuk \\ Prezes Polskiego Towarzystwa Medycyny Estetycznej i Anti-Aging \\ Estetol Med Kosmetol 2012; 2(4): 99-100 \\ DOI: http://dx.doi.org/10.14320/EMK.2012.020
}

\section{Streszczenie}

Artykut jest komentarzem prezesa Polskiego Towarzystwa Medycyny Estetycznej i Anti-Aging do niedawnych prób kreowania przez kolorowe magazyny „ekspertów medycyny estetycznej”. Autor zwraca uwagę, że czasopisma popularne zainteresowane są głównie zyskiem za wszelką cenę, a nie zapewnieniem wysokiej jakości usług medycznych. Nie są też powołane, ani nie mają kompetencji niezbędnych do oceny poziomu fachowego i etycznego lekarzy. Prezes Polskiego Towarzystwa Medycyny Estetycznej i Anti-Aging podkreśla, że budowanie wizerunku lekarza, w tym lekarza medycyny estetycznej, w oparciu o artykuły sponsorowane w czasopismach popularnych jest niezgodne z etyką lekarską i etykietą zawodową, a w dłuższej perspektywie przyczynia się do obniżenia wizerunku całego środowiska.

Stowa kluczowe: medycyna estetyczna, marketing, kryptoreklama, artykuty sponsorowane, profesjonalizm, etyka lekarska, etykieta zawodowa

\begin{abstract}
"All tricks allowed" - is a comment by the President of the Polish Society of Aesthetic and Anti-Aging Medicine on the recent situation in which illustrated magazines attempt to create "experts in aesthetic medicine". The author turns our attention to the fact that the popular press is interested primarily in making financial profit at any price, and not in ensuring the high quality of medical services. Mass media are not appointed, nor do they possess the competences necessary for assessing the professional and ethical merits of physicians. The President of the Polish Society of Aesthetic and Anti-Aging Medicine stresses that building the professional image of a doctor, including practitioners in aesthetic medicine, based upon sponsored articles in lay magazines, is against medical ethics and professional etiquette, and in the long-term perspective it may result in the deterioration of the standing of the whole professional group.
\end{abstract}

Keywords: aesthetic medicine, marketing, surreptitious advertising, sponsored articles, professionalism, professional ethics, professional etiquette

Copyright $\odot 2012$ the Authors (text) and Radosław Śpiewak (layout \& journal compilation). All rights reserved.

Żyjemy w rzeczywistości, w której każdy zna się przynajmniej na sporcie, prawie i medycynie. Rzeczywistości, w której można wykreować „eksperta” i „znawcę” z osoby nie mającej bladego pojęcia o danej materii. Regułą stał się brak reguł, a normą - brak jakichkolwiek norm. Ze smutkiem trzeba stwierdzić, że najlepiej w takiej rzeczywistości odnajdują się ludzie bez kręgosłupa, zmieniający zdanie jak rękawiczki, nie uznający żadnych zasad. Tak właśnie rodzą się różnej maści celebryci - osoby, które jak to się o nich trafnie mawia, ,znane są tylko z tego, że są znane”. Z zapałem sekundują im media goniące za sensacją, które od dawna już nie opisują rzeczywistości, lecz ją kreują. Nie może być na to zgody, gdy dotyczy to naszego zawodu. Medycyna estetyczna od początku swojej obecności w Polsce (a także w innych krajach) była traktowana z przymrużeniem oka, jako „mniej poważna medycyna”. Pamiętam to dobrze, ponieważ bez fałszywej skromności mogę stwierdzić, że wprowadzałem ją do Polski. Przez 20 lat jakie upłynęły od tego czasu dokładałem wszelkich starań, aby ta młoda gałąź medycyny nabywała jak najwięcej powagi, godności i „normalności”. Żywię przekonanie, że do pewnego stopnia udało się nam to wspólnie osiągnąć, jednak proces ten jeszcze się nie zakończył i ciągle wymaga naszej uwagi i troski. Niestety medycyna estetyczna wzbudza nadmierne zainteresowanie mediów, które chcą ten nośny temat wykorzystać do swoich interesów, przedstawiają zatem naszą dziedzinę jako mieszankę spektakularnych zabiegów, łatwych obietnic i „paramedycyny” doprawioną sutą dawką reklamy. Ten medialny wizerunek niewiele ma wspólnego z prawdziwą medycyną. Nasze - lekarzy grzechy w postaci zaniechań, braku godności, powagi i konsekwencji stają się pożywką dla pozbawionych skrupułów dziennikarzy. Z drugiej strony inicjatywy niezmiernie ważne zarówno dla środowiska lekarskiego, jak i pacjentów (na przykład propozycja kodeksu dobrych praktyk w naszej dziedzinie) nie cieszą się zainteresowaniem mediów jako „mało medialne”.

I oto pojawia się poświęcony medycynie estetycznej dodatek do popularnego lifestylowego czasopisma. Na okładce można przeczytać zapowiedź, że poznamy najlepszych lekarzy, najlepsze „kliniki”, dowiemy się najpilniej strzeżonych sekretów medycyny estetycznej. W rzeczywistości w zeszycie tym można znaleźć dziwaczną mieszankę reklam gabinetów lekarskich i kosmetycznych, niepohamowanej autopromocji pew- 
nych lekarzy i artykułów sponsorowanych pełnych rewelacji na temat różnorakich urządzeń i materiałów. Reklamy okraszone są zdjęciami lekarzy, którzy rozpływają się w zachwytach nad promowanymi produktami. Nie ma w tej publikacji jakiejkolwiek idei przewodniej, każdy plecie, co mu ślina na język przyniesie. Jeżeli usprawiedliwieniem dla tego wytworu jest ,wolność słowa", to gdzie podziała się odpowiedzialność za słowa? Brylujący w tym wydawnictwie lekarze to w większości stali bywalcy mediów. Niektórzy są dobrzy, większość chyba jednak nie wyrasta ponad przeciętną krajową (o ile mogę sobie na taką subiektywną opinię pozwolić). Trudno dociec, na czym miałaby polegać ich przewaga jako „najlepszych lekarzy”. Dlaczego oni, a nie inni? - Nie wiadomo. Kim są osoby, które uzurpują sobie prawo wystawiania ocen ,ty jesteś bardzo dobrym lekarzem, a on nim nie jest"? - Nie wiadomo. Dlaczego za ferowanie wyroków na temat fachowości lekarzy wzięło się pismo z założenia „lekkie, łatwe i przyjemne"? - Nie wiadomo. Dlaczego o komentarz do tego ,rankingu” nie zostało poproszone żadne z oficjalnych towarzystw naukowych medycyny estetycznej czy chirurgii plastycznej? - Nie wiadomo. Jedną z możliwych odpowiedzi mogą być opłaty, jakie zapewne musieli ponieść lekarze pragnący znaleźć się w gronie wymienionych ,ekspertów”. Nie ma o tym wzmianki w opisywanym dodatku. Czy doszło do kryptoreklamy, celowej dezinformacji i uzurpacji przez wydawnictwo roli jury osądzającego który lekarz jest „wybitnym specjalistą”, a który nie? Uderzające, że nie spotyka się tego typu publikacji na temat klasycznych specjalizacji lekarskich, na przykład kardiologii, pediatrii czy ginekologii...

Nie może być zgody naszego środowiska na tego rodzaju praktyki. Nie może być tak, by anonimowe i przypadkowe osoby w sposób autorytarny decydowały kto jest, a kto nie jest dobrym lekarzem. List protestacyjny w tej sprawie został wysłany do redakcji owego niefortunnego periodyku, kolegom lekarzom medycyny estetycznej zwrócono uwagę na te karygodne praktyki. Także Polskie Towarzystwo Chirurgii Plastycznej i Rekonstrukcyjnej jest zgodne w tej kwestii ze stanowiskiem Polskiego Towarzystwa Medycyny Estetycznej i Anti-Aging. Stanowiska obu towarzystw odzwierciedlają powszechny sprzeciw środowisk lekarskich Europy wobec reklamowania usług medycyny estetycznej [1-4]. Stanowisko środowisk wszystkich krajów Unii Europejskiej powinno być jednolite, szczególne w warunkach coraz bardziej popularnej ,turystyki medycznej”[5].

Na koniec przytoczę stare powiedzenie „nic o nas bez nas". Dbajmy o nasze dobre imię i powagę naszej profesji. Nie możemy pozwolić, aby przypadkowe osoby, nie znając ani środowiska, ani nie posiadając kwalifikacji do rzetelnej oceny lekarzy, uzurpowały sobie rolę „wyroczni”, czyniąc tak zapewne nie dla idei, ani dla dobra pacjenta. Jako lekarze powinniśmy z wyjątkową ostrożnością podchodzić do tych wątpliwych praktyk. Media mogą nas jednego dnia wynieść na celebryckie szczyty, by następnego strącić w niebyt lub niesławę.

\section{Piśmiennictwo}

1. Graham N: The hard sell in cosmetic surgery advertising. BMJ 2010;340:c1223.

2. O'Dowd A: Surgeons' leaders call for ban on cosmetic surgery advertising. BMJ 2012;344:e627.

3. Godlee F: Promoting cosmetic surgery. BMJ 2012;345:e7535.

4. Fatah F: Should all advertising of cosmetic surgery be banned? Yes. BMJ 2012;345:e7489.

5. Hanefeld J, Lunt N, Horsfall D, Smith R: Discussion on banning advertising of cosmetic surgery needs to consider medical tourists. BMJ 2012;345:e7997.

\section{Adres do korespondencji}

dr med. Andrzej Ignaciuk

Polskie Towarzystwo Medycyny Estetycznej

i Anti-Aging

Polskie Towarzystwo Lekarskie Oddział w Warszawie

Aleje Ujazdowskie 22 lokal 2

00-478 Warszawa

E-mail: a_ignaciuk@wp.pl

Data złożenia: 5.11 .2012

Data akceptacji: 7.11.2012 